\title{
Titanium dioxide nanoparticles perturb the blood-testis barrier via disruption of actin-based cell adhesive function
}

\author{
Dong-Qi Ni2,4,5,*, Dan-Dan Ma2,", Shuang-Li Hao 2,, ${ }^{*}$ Wan-Xi Yang ${ }^{2}$, Tamas Kovacs ${ }^{3}$, \\ Fu-Qing $\operatorname{Tan}^{1}$
}

${ }^{1}$ The First Affiliated Hospital, College of Medicine, Zhejiang University, Hangzhou 310003, Zhejiang, China

${ }^{2}$ The Sperm Laboratory, College of Life Sciences, Zhejiang University, Hangzhou 310058, Zhejiang, China

${ }^{3}$ Department of Obstetrics and Gynaecology, Faculty of Medicine, University of Debrecens, Debrecen 4032, Hungary

${ }^{4}$ CAS Key Laboratory for Biomedical Effects of Nanomaterials and Nanosafety and CAS Center for Excellence in Nanoscience, National Center for Nanoscience and Technology, Beijing 100190, China

${ }^{5}$ University of Chinese Academy of Sciences, Beijing 100049, China

*Equal contribution

Correspondence to: Wan-Xi Yang, Tamas Kovacs, Fu-Qing Tan; email: wxyang@zju.edu.cn, kt@med.unideb.hu, drtfq@zju.edu.cn

Keywords: $\mathrm{TiO}_{2}-\mathrm{NPs}$, blood-testis barrier, $\mathrm{TM}-4$ cell, tight junction, actin

Received: October 29, 2019 Accepted: August 11, $2021 \quad$ Published: December 14, 2021

Copyright: (c) $2021 \mathrm{Ni}$ et al. This is an open access article distributed under the terms of the Creative Commons Attribution License (CC BY 3.0), which permits unrestricted use, distribution, and reproduction in any medium, provided the original author and source are credited.

\section{ABSTRACT}

As one of the most commonly used nanoparticles, titanium dioxide nanoparticles $\left(\mathrm{TiO}_{2}\right.$ - $\mathrm{NPs}$ ) are widely used as coating reagents in cosmetics, medicine and other industries. The increasing risk of exposure to $\mathrm{TiO}_{2}$-NPs raises concerns about their safety. In this study, we investigated the mechanism by which $\mathrm{TiO}_{2}-\mathrm{NPs}$ cross the bloodtestis barrier (BTB). TM-4 cells were selected as an in vitro Sertoli cell model of BTB. Cell viability, cell morphological changes, apoptosis, oxidative damage, and the expression levels of actin regulatory and tight junction (TJ) proteins were assessed in TM-4 cells treated with 3-nm and 24-nm $\mathrm{TiO}_{2}-\mathrm{NPs}$. Cells treated with 3-

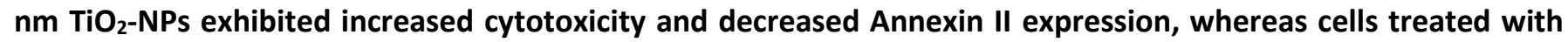
24-nm $\mathrm{TiO}_{2}$-NPs exhibited increased Arp 3 and c-Src expression. Both $\mathrm{TiO}_{2}-\mathrm{NPs}$ induced significant oxidative stress, decreased the expression of TJ proteins (occludin, ZO-1 and claudin 5), damaged the TJ structure, and exhibited enlarged gaps between TM-4 cells. Our results indicated that both $\mathrm{TiO}_{2}$-NPs crossed the BTB by disrupting actin-based adhesive junctions of TM-4 cells; however, apoptosis was not observed. Our results provide new insights into how $\mathrm{TiO}_{2}$-NPs cross the BTB.

\section{INTRODUCTION}

Approximately $15 \%$ of couples in Western countries are affected by infertility, among which males contribute to greater than half of the cases [1]. Over the past decades, a reduction in semen quality and count and an increasing number of infertile men have been reported [2]. Therefore, it is crucial to discover the underlying biological relevance of these changes. A previous study reported that environmental pollutants can cause infertility [3]. Nanoparticles (NPs) and other environmental pollutants cause sperm apoptosis and a reduction in sperm quality $[4,5]$.

Particles between 1-100 $\mathrm{nm}$ in size are referred to as NPs, and these new materials have been rapidly applied in various industries (e.g., electronics, chemical industry, biology, medicine) and daily life [6]. Multiple engineered nanoparticles (ENPs) have been produced, including metal NPs, such as 
platinum, gold, and silver; metal oxide NPs, such as $\mathrm{TiO}_{2}, \mathrm{ZnO}$, and $\mathrm{Fe}_{2} \mathrm{O}_{3}$; and carbon nanomaterials, such as $\mathrm{C}_{60}$ fullerenes and carbon nanotubes [7]. The high ratio of the surface area to volume of small ENPs provides these particles with unique physico-chemical properties and enhanced biological activity compared to other particles and poses a threat to the environment [8]. Mucosal, skin and organ toxicities caused by ENPs were observed in the human body after oral, skin, and respiratory exposures and injection [9]. Furthermore, ENPs can cross the bloodbrain barrier (BBB) and promote the expression of proinflammatory cytokines, including IL- $1 \alpha$, TNF- $\alpha$ and NF- $\kappa \mathrm{B}$ [10], which may increase the risks of neurodegenerative disease and brain cancer. ENPs can also cross BTB and alter the spermatogenesis process by inducing apoptosis or necrosis of spermatocytes and Sertoli cells as well as reducing sperm motility, quality and quantity [11-13].

$\mathrm{TiO}_{2}$-NPs are one of the top five ENPs used in pharmaceutical products which are less cytotoxic and cytostatic to primary testicular cells than silver NPs [14]. $\mathrm{TiO}_{2}$-NPs are widely used in various products (e.g., cosmetics, paint, sunscreens, etc.) and play a key role in the development of nanotechnology [15]. Nevertheless, recent papers have reported that $\mathrm{TiO}_{2-}$ NPs can impact the male reproductive system in various ways. As endocrine disruptors, $\mathrm{TiO}_{2}-\mathrm{NPs}$ influence the synthesis of serum testosterone and eventually lead to reduced spermatogenesis in mice [16]. Furthermore, long-term exposure to $\mathrm{TiO}_{2}-\mathrm{NPs}$ could induce low fertility and inflammation in the testis, which might be associated with dysfunction of the TAM/TLR3 signaling pathway [17]. Microarray analysis revealed significant alterations in the expression of genes related to spermatogenesis and testicular function upon exposure to $\mathrm{TiO}_{2}$-NPs [18]. The cytotoxic and genotoxic properties of $\mathrm{TiO}_{2}-\mathrm{NPs}$ were assumed to affect the fertilizing potential of spermatozoa [19].

The BTB, which differs from other blood-tissue barriers, is created by coexisting TJs, basal ectoplasmic specialization (ES) and gap junctions (GJs) between adjacent Sertoli cells close to the base of the seminiferous tubule [20]. In addition, ectoplasmic specialization is a unique structure enriched with F-actin in the seminiferous epithelium that supports BTB function [21]. Sertoli cells have been isolated from humans and rodents to study functional $\mathrm{TJ}$ permeability, and these cells serve as an in vivo model to study the molecular mechanisms of TJ and BTB [22]. The mouse Sertoli cell line (TM-4) is one of the most extensively studied Sertoli cell models; these cells have been used to assess the reproductive toxicity of ENPs [23] and in BTB studies [24-26].

The underlying mechanisms of ENPs crossing BTB remain unclear. In 2012, Lan and Yang proposed the "elevator door" hypothesis [27] wherein ENPs exert inflammatory responses, which weakened BTB integrity. However, the mechanism by which microparticles that do not induce inflammatory responses cross BTB remains unknown. In our work, we studied the cytotoxic effects of 3-nm and 24-nm $\mathrm{TiO}_{2}-\mathrm{NPs}$ in TM-4 cells and assessed the underlying mechanisms of $\mathrm{TiO}_{2}-\mathrm{NPs}$ crossing BTB. We also assumed two mechanisms: (1) $\mathrm{TiO}_{2}-\mathrm{NPs}$ alter the expression and organization of $\mathrm{TJ}$ proteins, which damage the integrity of the $\mathrm{BTB}$; (2) $\mathrm{TiO}_{2}-\mathrm{NPs}$ induce oxidative damage and apoptosis, and the loss of Sertoli cells also results in a comprised BTB.

\section{RESULTS}

\section{Cytotoxicity of $\mathrm{TiO}_{2}-\mathrm{NPs}$}

Both sizes of $\mathrm{TiO}_{2}$-NPs showed uniform and good dispersibility (Supplementary Figure 1). TM-4 cells were incubated with two different sizes of $\mathrm{TiO}_{2}$-NPs at a series of concentrations $(0-100 \mu \mathrm{g} / \mathrm{ml})$ for $24 \mathrm{~h}$, and concentration-dependent cytotoxicity of $\mathrm{TiO}_{2}-\mathrm{NPs}$ was observed (Figure 1). The cytotoxicity of 3-nm $\mathrm{TiO}_{2}-\mathrm{NPs}$ was greater than that of 24-nm $\mathrm{TiO}_{2}$-NPs. The median lethal concentration of 3-nm $\mathrm{TiO}_{2}-\mathrm{NPs}$ was $\sim 60 \mu \mathrm{g} / \mathrm{ml}$, and 24-nm $\mathrm{TiO}_{2}-\mathrm{NPs}$ at similar concentrations also showed a significant decrease in cell viability. Moreover, exposure of TM- 4 cells to two sizes of $\mathrm{TiO}_{2}$-NPs at 25 $\mu \mathrm{g} / \mathrm{ml}$ resulted in greater than $80 \%$ viability. We chose these two concentrations ( 30 and $60 \mu \mathrm{g} / \mathrm{ml}$ ) of $\mathrm{TiO}_{2}-\mathrm{NPs}$ for further experiments based on the observed results.

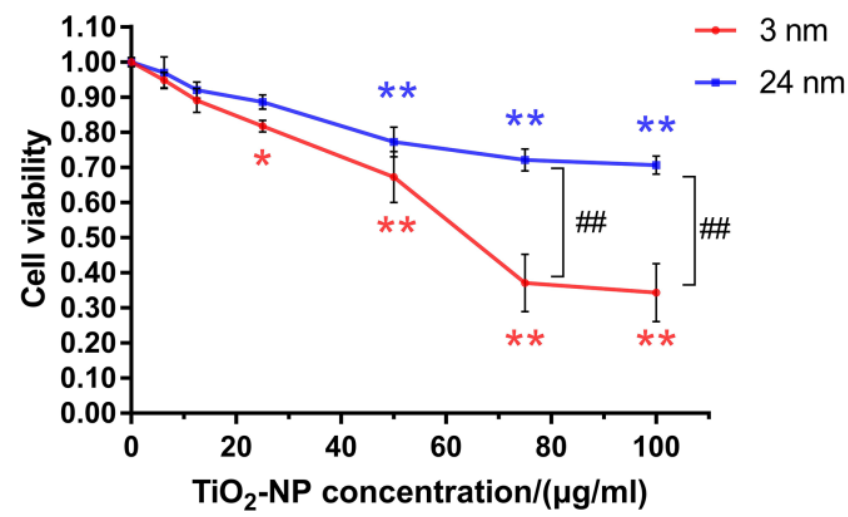

Figure 1. The effects of $\mathrm{TiO}_{2}$-NPs on $\mathrm{TM}-4$ cell viability after exposure for $\mathbf{2 4} \mathrm{h}$. The results are expressed as the mean \pm SEM. $\mathrm{n}=4,{ }^{*} p<0.05, * * p<0.01$ compared to the control; $\# \#<0.01$ compared to the NPs. 


\section{Assessment of the expression of actin regulatory proteins induced by $\mathrm{TiO}_{2}$-NPs}

The expression of actin regulatory proteins (actinrelated protein 3 (Arp 3), Annexin II and a nonreceptor protein tyrosine kinase (c-Src)) in TM-4 cells treated with $\mathrm{TiO}_{2}-\mathrm{NPs}$ at both concentrations was detected by western blotting (WB). Arp 3 helps to promote junction restructuring. Annexin II is a putative substrate of c-Src proteins, and $\mathrm{c}-\mathrm{Src}$ protein is an integrated component of the BTB and apical ES in the testis [21, 28, 29]. The expression of actin regulatory proteins of TM- 4 cells changed after $24 \mathrm{~h}$ of exposure to $\mathrm{TiO}_{2}$-NPs at two different concentrations (Figure 2). The expression of Arp 3 and $\mathrm{c}-\mathrm{Src}$ increased after exposure to $24-\mathrm{nm} \mathrm{TiO}_{2}-$ NPs, but exposure to $3-\mathrm{nm} \quad \mathrm{TiO}_{2}$-NPs had no significant effect on expression. However, the level of Annexin II expression was slightly reduced upon exposure to $3-\mathrm{nm} \mathrm{TiO}_{2}-\mathrm{NPs}(30$ or $60 \mu \mathrm{g} / \mathrm{ml}$ ) for $24 \mathrm{~h}$.

\section{Investigating reductions in BTB-associated protein expression induced by $\mathrm{TiO}_{2}$-NPs}

BTB-associated proteins ZO-1 (zonula occludens-1, binds connective transmembrane proteins to the actin cytoskeleton), claudin 5 (a member of claudin family that includes integral transmembrane proteins), occludin (a tight junctional transmembrane protein), N-cadherin (a transmembrane molecule mediating calciumdependent intercellular adhesion), and $\beta$-catenin (an adherens junction protein regulating adhesion between cells) were detected by WB after treatment with $\mathrm{TiO}_{2-}$ NPs. ZO-1 and claudin 5 expressions were decreased, whereas $\beta$-catenin expression notably increased after treatment with two different $\mathrm{TiO}_{2}$-NPs (30 and 60 $\mu \mathrm{g} / \mathrm{ml})$. However, a decrease in occludin expression was mainly observed upon exposure to high $(60 \mu \mathrm{g} / \mathrm{ml})$ concentrations of $\mathrm{TiO}_{2}$-NPs in TM-4 cells. In addition, pretreatment with NAC partially rescued the adverse effect of $\mathrm{TiO}_{2}-\mathrm{NPs}$ on BTB-associated protein expression (Figure 3).

\section{Expanded junction gaps and $\mathbf{F}$-actin remodeling in TM-4 cells induced by $\mathrm{TiO}_{2}$-NPs}

TM-4 cells tend to spread on the bottom of the culture plate and have typical epithelioid, protruding morphologies [30]. The edge of the cells overlapped with the long microvilli, which extended from one cell to another [31]. However, after $24 \mathrm{~h}$ of treatment with $\mathrm{TiO}_{2}$-NPs of both sizes ( 30 and $60 \mu \mathrm{g} / \mathrm{ml}$ ), the number

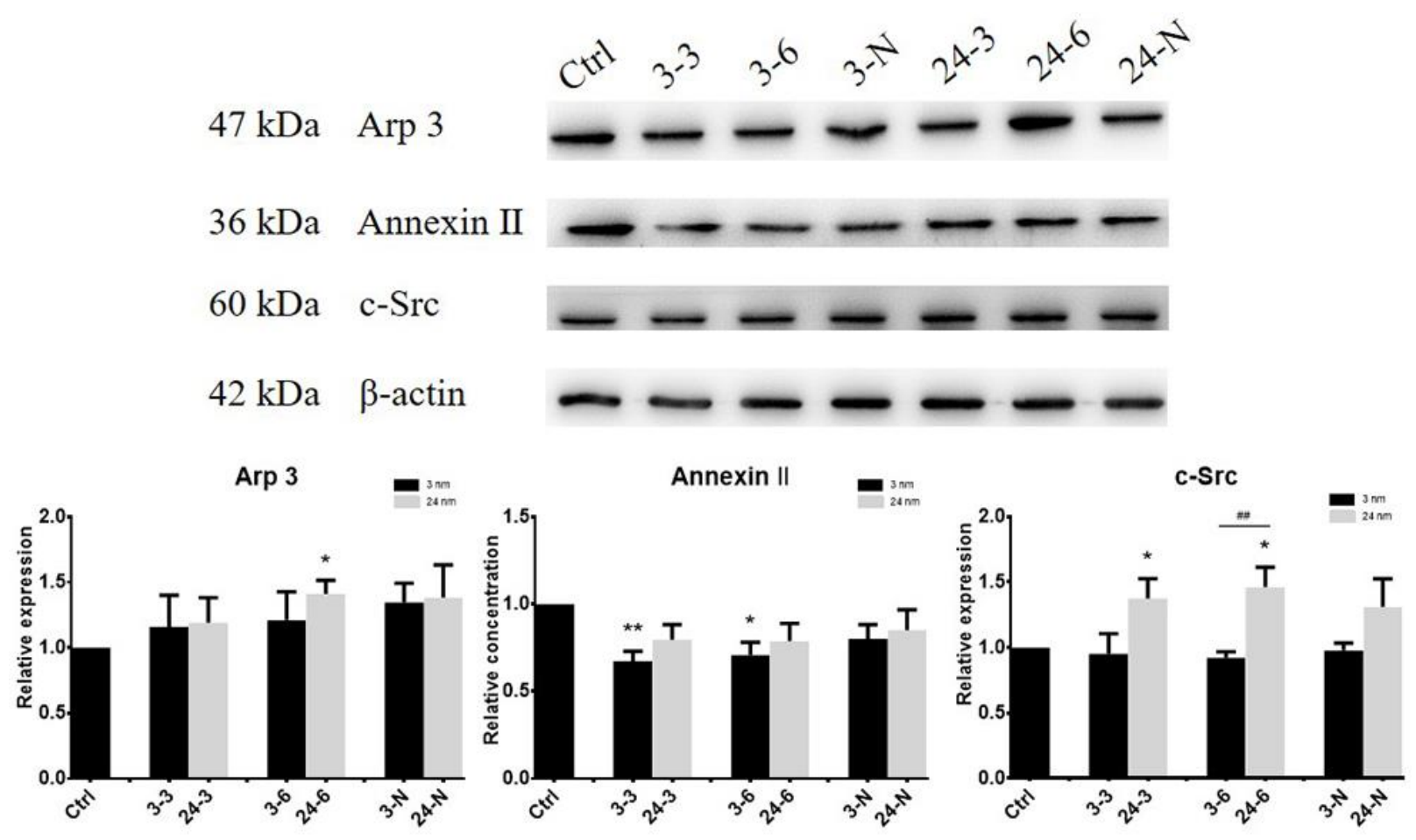

Figure 2. The expression of actin regulatory proteins (Arp 3, Annexin II and c-Src) in TM-4 cells treated with two different concentrations of $\mathrm{TiO}_{2}-\mathrm{NPs}$ for $\mathbf{2 4} \mathrm{h}$. "3-3": $30 \mu \mathrm{g} / \mathrm{ml}$, "3-6": $60 \mu \mathrm{g} / \mathrm{ml}$, "3-N": TM-4 cells were treated with $5 \mathrm{mM}$ NAC for $2 \mathrm{~h}$ and then treated with $60 \mathrm{\mu g} / \mathrm{ml}$ 3-nm TiO $-\mathrm{NPs}$ for $24 \mathrm{~h}$. "24-3": $30 \mu \mathrm{g} / \mathrm{ml}$, "24-6": $60 \mu \mathrm{g} / \mathrm{ml}$, "24-N": TM-4 cells were treated with $5 \mathrm{mM}$ NAC for $2 \mathrm{~h}$ and then treated with $60 \mu \mathrm{g} / \mathrm{ml}$ of $24-\mathrm{nm} \mathrm{TiO}_{2}$-NPs for $24 \mathrm{~h} . \mathrm{n}=5,{ }^{*} p<0.05,{ }^{* *} p<0.01$ compared to the control; \#\#p<0.01 compared to the NPs. 
of agglomerated TM-4 cells (that did not adhere to the bottom) increased, and this effect was partially influenced by $2 \mathrm{~h}$ of pretreatment with NAC (Supplementary Figure 2). The density of well-attached cells after treatment with 3-nm NPs was significantly reduced compared with that noted after treatment with 24-nm NPs at the same concentrations. In normal TM-4 cells, F-actin organized to form an extensive network at the Ectoplasmic Specialization (ES) site (Figure 4). Factin was depolymerized and then repolymerized into thick bundles in TM-4 cells treated with $\mathrm{TiO}_{2}-\mathrm{NPs}$ (Figure 4). Both $\mathrm{TiO}_{2}$-NPs induced elongated fusiform morphology of TM-4 cells (Figure 4 and Supplementary Figure 2). Additionally, NAC rescued the effect of $\mathrm{TiO}_{2}$-NPs on morphology (Figure 4 and Supplementary Figure 2D, 2G).

The spatial distribution of BTB-associated proteins, including $\beta$-catenin, $\mathrm{ZO}-1$, and $\mathrm{N}$-cadherin, was detected by immunofluorescence (IF). After treatment with $\mathrm{TiO}_{2}-\mathrm{NPs}$, these three $\mathrm{BTB}$-associated proteins between cells were damaged. In addition, a change in their spatial distribution was noted, and the intercellular gap was expanded significantly (Figure 4).

\section{$\mathrm{TiO}_{2}$-NPs did not induce $\mathrm{TM}-4$ cell apoptosis}

TM-4 cell apoptosis was not observed after treatment with either concentration or size of $\mathrm{TiO}_{2}-\mathrm{NP}$ (Figure 5). Similar to the control, the cells treated with the NPs did not show any obvious apoptotic signals (red fluorescence) when measured using the TUNEL method (Figure 5A). Additionally, caspase 3/8/9 activity showed negligible changes in TM-4 cells after treatment with $\mathrm{TiO}_{2}$-NPs (Figure 5B).

\section{Oxidative stress in $\mathrm{TM}-4$ cells treated with $\mathrm{TiO}_{2}-\mathrm{NPs}$}

A significant decrease in catalase (CAT) activity was observed in TM-4 cells treated with $30 \mu \mathrm{g} / \mathrm{ml} \mathrm{TiO}_{2}-\mathrm{NPs}$

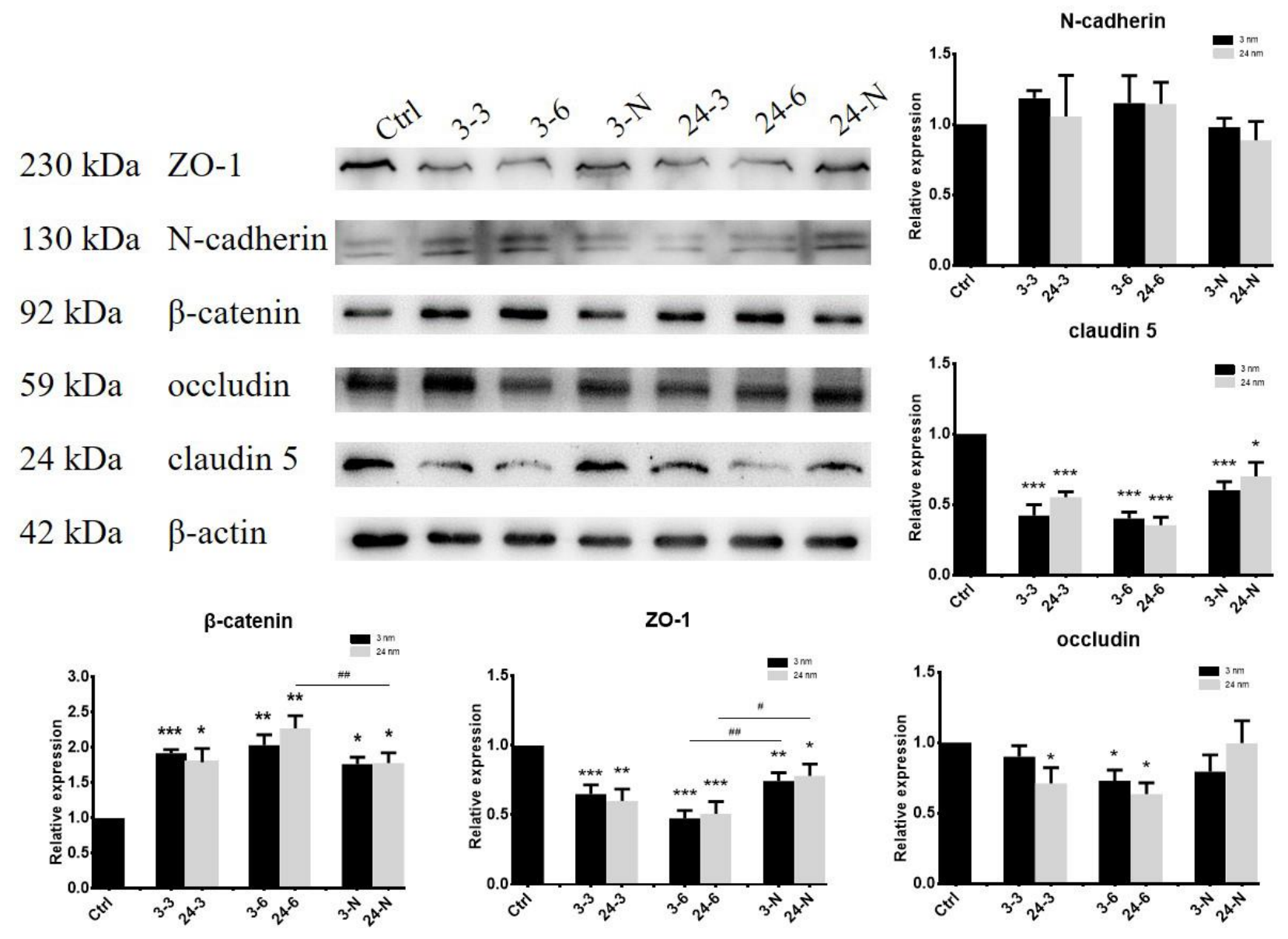

Figure 3. The expression of BTB-associated proteins in TM-4 cells upon treatment with two different concentrations of TiO ${ }_{2}$ NPs for 24 h. "3-3": $30 \mu \mathrm{g} / \mathrm{ml}$, "3-6": $60 \mu \mathrm{g} / \mathrm{ml}$, "3-N": TM-4 cells were treated with $5 \mathrm{mM} \mathrm{NAC}$ for $2 \mathrm{~h}$ and then treated with $60 \mathrm{\mu g} / \mathrm{ml} 3-\mathrm{nm}$ $\mathrm{TiO}_{2}$-NPs for 24 h. "24-3": $30 \mu \mathrm{g} / \mathrm{ml}$, "24-6": $60 \mu \mathrm{g} / \mathrm{ml}$, "24-N": TM-4 cells were treated with $5 \mathrm{mM}$ NAC for 2 h and then treated with 60

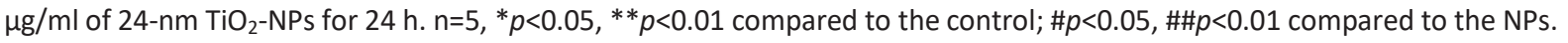


for $24 \mathrm{~h}$ (Figure 6A), whereas no significant change in CAT activity was observed upon exposure to $60 \mu \mathrm{g} / \mathrm{ml}$ of either $\mathrm{TiO}_{2}-\mathrm{NP}$. Hydrogen peroxide levels were enhanced in TM-4 cells treated with two different $\mathrm{TiO}_{2}-$ NPs (Figure 6B).

\section{DISCUSSION}

At present, in vitro studies of BTB have been performed using rat or human primary cultured Sertoli cells [32-34]. However, studies on the mouse BTB are rare, and most of these studies involved toxicological research on mouse primary cultured Sertoli cells [35]. The BTB consists of TJs, GPs and adhesion junctions between adjacent Sertoli cells of the testis and functions as a suitable microenvironment for spermatogenesis [36]. ENPs exert destructive effects on BTB function via disruption of Sertoli cell junctional proteins, oxidative stress, cell apoptosis, and others [32, 37, 38].

The present study showed that the toxicity of $\mathrm{TiO}_{2}-\mathrm{NPs}$ to TM-4 cells was concentration- and size-dependent
[39-41]. The higher $\mathrm{TiO}_{2}$-NPs concentration showed greater toxicity to TM-4 cells. Meanwhile, the smaller sized $\mathrm{TiO}_{2}-\mathrm{NPs}$ presented higher toxicity to TM-4 cells. This finding might be due to the mass-specific surface area of small ENPs, which enhanced their bioactivity $[42,43]$. In this study, TM-4 cells were treated with two concentrations (30 and $60 \mu \mathrm{g} / \mathrm{ml}$ ) of $\mathrm{TiO}_{2}-\mathrm{NPs}$ (3 and $24 \mathrm{~nm}$ ) and did not undergo apoptosis. Hong et al. reported that primary cultured mouse Sertoli cells treated with 15 and $30 \mu \mathrm{g} / \mathrm{ml} 5-\mathrm{nm}$ $\mathrm{TiO}_{2}$-NPs for $24 \mathrm{~h}$ underwent apoptosis $(32.52 \%$ and $21.02 \%$, respectively) [35], whereas Mao et al. found that $21-\mathrm{nm} \mathrm{TiO}_{2}$ (up to $100 \mu \mathrm{g} / \mathrm{ml}$ for $24 \mathrm{~h}$ ) did not reduce cell viability but induced apoptosis in TM-4 cells [41]. This finding indicates that the cytotoxic effects of $\mathrm{TiO}_{2}$ on mouse Sertoli cells is based on the sizes of $\mathrm{TiO}_{2}$-NPs and cell types.

The BTB is a strong structure composed of Sertoli cells, vascular endothelial basement membrane, connective tissue, and compact tubule basement membrane. The BTB prevents cytotoxic substances from entering the seminiferous tubules to avoid the influence of foreign

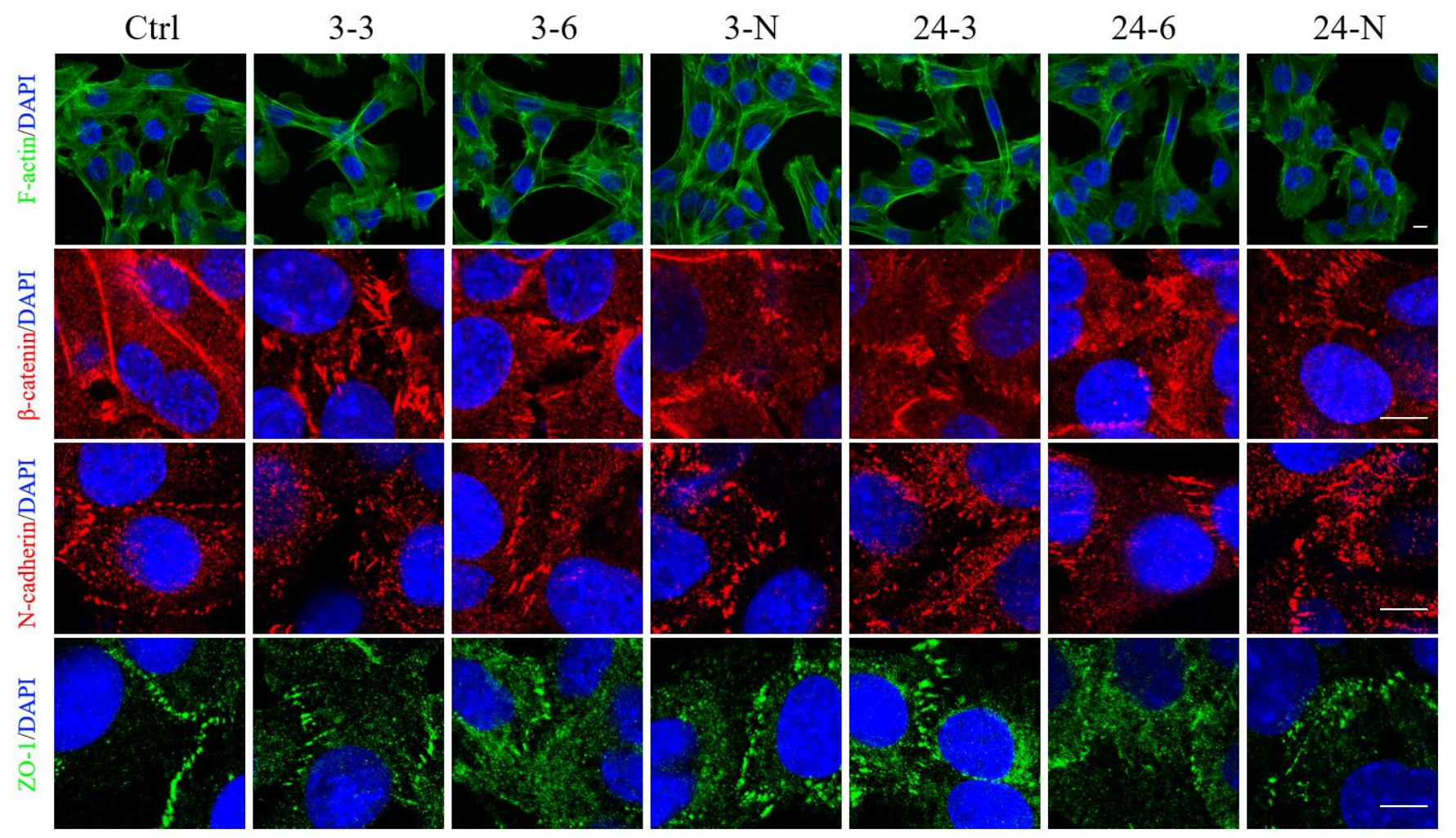

Figure 4. The spatial distributions of F-actin and BTB-associated proteins in TM-4 cells treated with two different concentrations of $\mathrm{TiO}_{2}-\mathrm{NPs}$ for $\mathbf{2 4} \mathrm{h}$. The distribution of intracellular microfilaments (F-actin) and the distribution of BTB-associated proteins: ZO-1 (green), N-cadherin (red), and $\beta$-catenin (red). "3-3": $30 \mu \mathrm{g} / \mathrm{ml}$, "3-6": $60 \mu \mathrm{g} / \mathrm{ml}$, "3-N": TM-4 cells were treated with 5

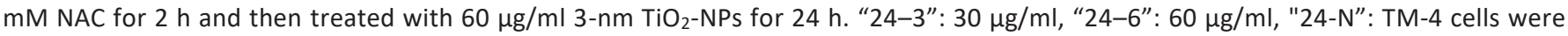
treated with $5 \mathrm{mM} \mathrm{NAC}$ for $2 \mathrm{~h}$ and then treated with $60 \mu \mathrm{g} / \mathrm{ml}$ of $24-\mathrm{nm} \mathrm{TiO} \mathrm{T}_{2}-\mathrm{NPs}$ for $24 \mathrm{~h}$. Scale bar=10 $\mu \mathrm{m}$. 
substances on spermatogenic cells. In normal Sertoli cells from rats and humans, F-actin was distributed in organized bundles in the cell membrane [20, 28, 44]. In this study, F-actin was transformed from a wellorganized and fine structure to a thick polymerized bundle-like structure after exposure to $\mathrm{TiO}_{2}$-NPs. This change is due to the effects of $\mathrm{TiO}_{2}$-NPs on the expression of actin regulatory proteins, including Arp 3, Annexin II and c-Src, which are all involved in the depolymerization and polymerization of F-actin
$[21,36,37]$. The reorganization of F-actin caused changes in the spatial organization of actin in ES, which affects the overall structure of the tight junction.

TJs are the main structure of the BTB and include claudins, occludin, $\mathrm{ZO}$ proteins among others [45]. As the first TJ transmembrane protein discovered [46], occludin is responsible for regulating the barrier properties of TJs [47]. ZO-1 belongs to the family of membrane-associated guanylate kinase proteins [20] and
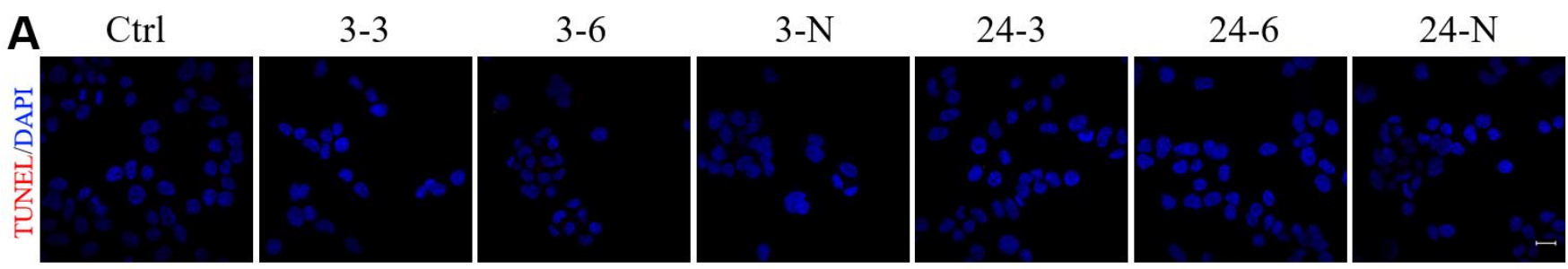

B
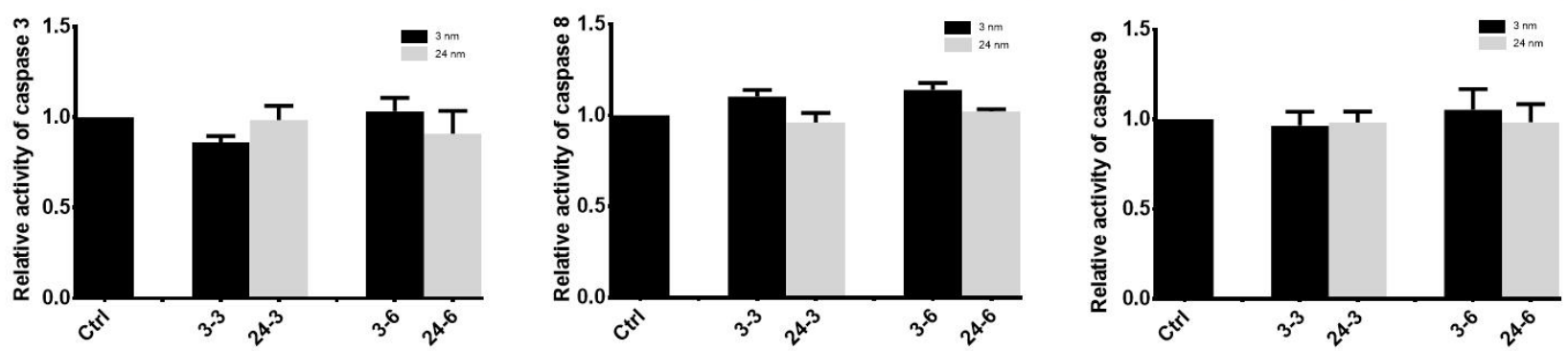

Figure 5. The effect of $\mathrm{TiO}_{2}$-NPs on TM-4 cell apoptosis. (A) TUNEL results revealed no apoptosis signals (red fluorescence) in TM-4 cells treated with $\mathrm{TiO}_{2}$-NPs. (B) Caspase 3/8/9 activity in cells treated with $\mathrm{TiO}_{2}$-NPs showed no obvious changes. The results were expressed as the mean \pm SEM. $n=4$, Scale bar $=20 \mu \mathrm{m}$.

A

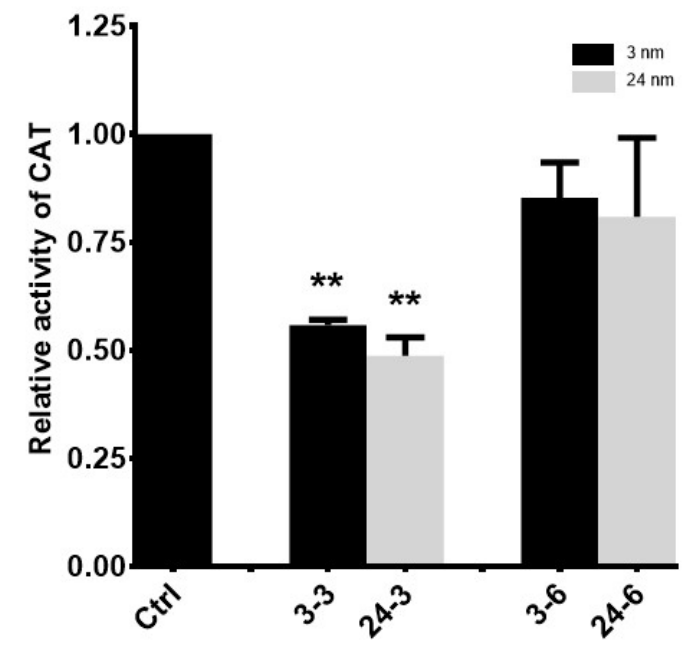

B

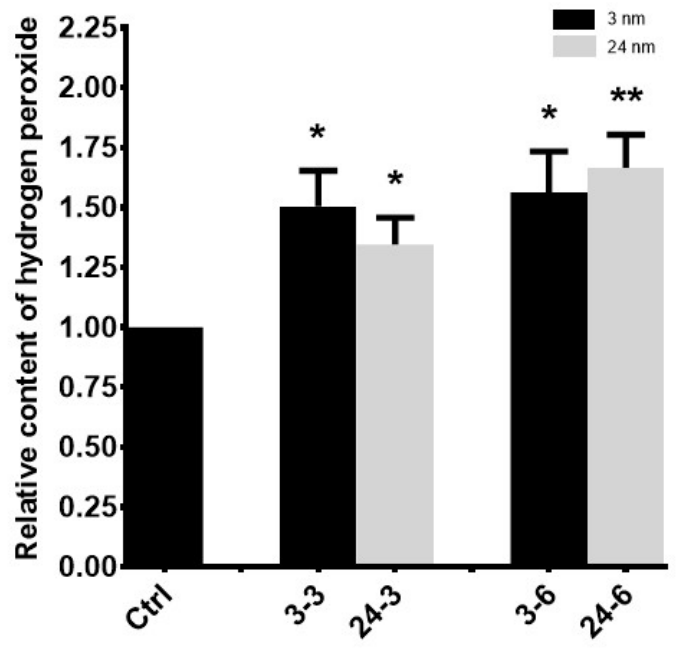

Figure 6. Oxidative stress in TM-4 cells treated with $\mathrm{TiO}_{2}-\mathrm{NPs}$. (A) Intracellular CAT activity in TM-4 cells treated with $\mathrm{TiO}_{2}-\mathrm{NPs}_{\mathrm{S}}$ for 24 h. (B) Intracellular hydrogen peroxide levels in TM-4 cells treated with $\mathrm{TiO}_{2}-\mathrm{NPs}$ for $24 \mathrm{~h}$. The results are expressed as the mean \pm SEM. $\mathrm{n}=7$, ${ }^{*} p<0.05,{ }^{* *} p<0.01$ compared to the control. 
provides a linkage between the actin cytoskeleton and TJ proteins, such as occludin, JAMs and claudins [48]. Claudin 5, a member of the claudin family, which comprise the major component of TJ strands, is an integral membrane protein that shares the transmembrane domains of occludin [49]. Claudin 5 knockout caused spermatogenic cells to fall off into the seminiferous tubule lumen [50]. N-cadherin and $\beta$ catenin are adhesion protein complexes that assemble at the Sertoli cell-cell interface to form cell adhesion [28]. Our results demonstrated that two different sizes of $\mathrm{TiO}_{2}$-NPs could decrease the levels of $\mathrm{ZO}-1$, occludin and claudin 5 in TM-4 cells and perturb the spatial positions of $\mathrm{ZO}-1, \mathrm{~N}$-cadherin and claudin 5. In contrast, the gaps were increased, indicating that $\mathrm{TiO}_{2-}$ NPs expanded TJ gaps.

Hong et al. reported that 5-nm $\mathrm{TiO}_{2}-\mathrm{NPs}$ reduced CAT activity in mouse Sertoli cells and induced oxidative damage in these Sertoli cells [35]. Our results revealed a similar oxidative stress response. Moreover, pretreatment with NAC (antioxidant) partly rescued the decrease in cell-cell junction proteins and the morphology of TM-4 cells treated with $\mathrm{TiO}_{2}$-NPs according to the western blot and immunofluorescence results. These findings indicate that oxidative stress is one of the factors that disrupts the connection between TM-4 cells and $\mathrm{TiO}_{2-}$ NPs.

Taken together, $\mathrm{TiO}_{2}$-NPs damage the spatial structure of BTB-associated proteins and reorganize the cytoskeletal structure. We further confirmed that $\mathrm{TiO}_{2}$-NPs induce oxidative stress to perturb the content of BTB-associated and actin regulatory proteins, thus affecting the structure of TJs and the cytoskeleton (Figure 7). Our study showed that $\mathrm{TiO}_{2-}$ NPs of both sizes could expand the BTB gaps to allow small $\mathrm{TiO}_{2}$-NPs to cross the BTB and affect spermatogenesis.

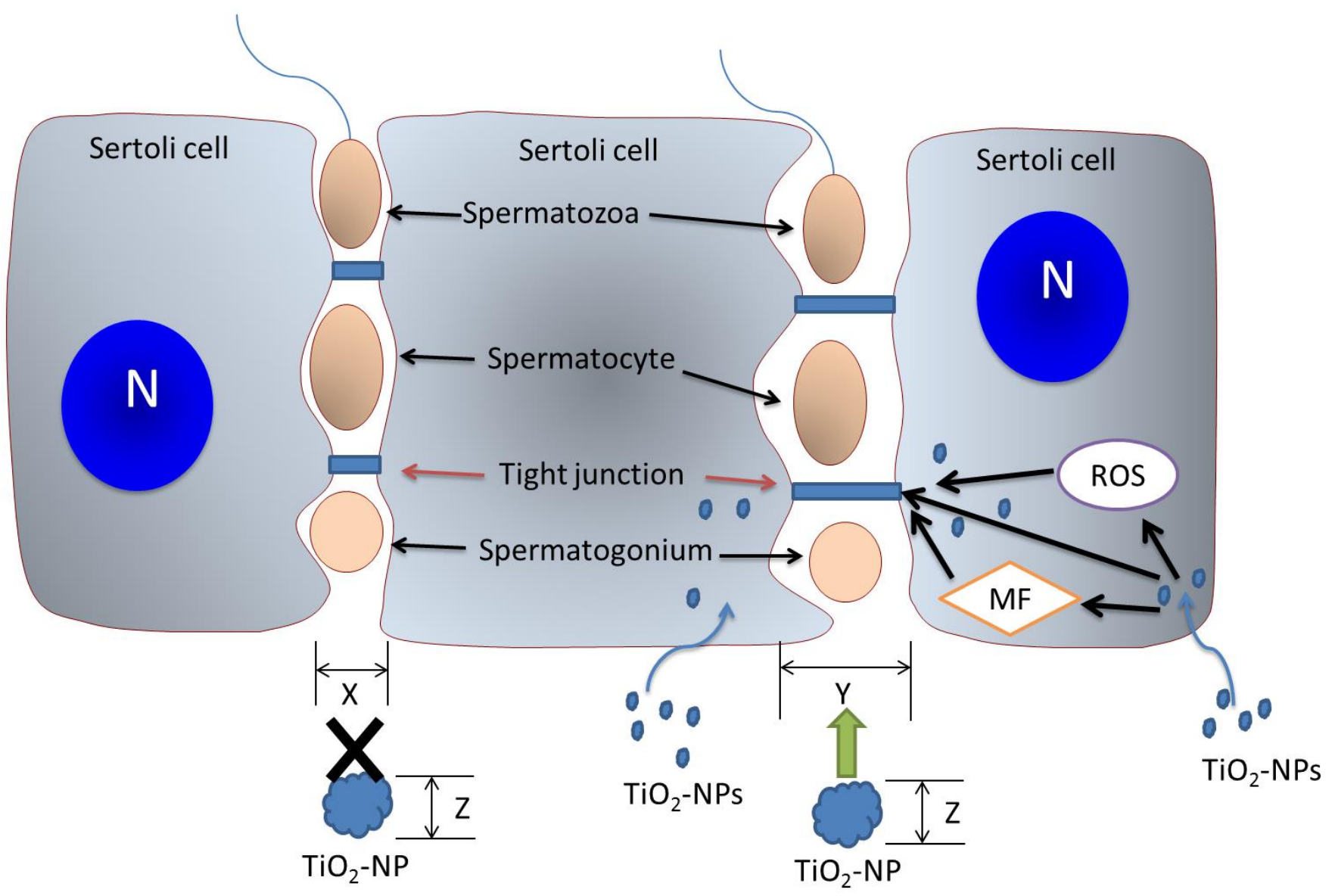

Figure 7. The mechanism of action of $\mathrm{TiO}_{2}-\mathrm{NPs}$ on $\mathrm{BTB}$. $\mathrm{TiO}_{2}-\mathrm{NPs}$ damage the $\mathrm{BTB}$ via three mechanisms. $\mathrm{TiO}_{2}-\mathrm{NPs}$ interfere with $\mathrm{BTB}-$ associated proteins, induce cytoskeletal reorganization, and trigger oxidative stress to perturb TJ proteins. The BTB gap (size $X$ ) is expanded (size $\mathrm{Y}$ ) by $\mathrm{TiO}_{2}-\mathrm{NPs}$, and $\mathrm{TiO}_{2}$-NPs (particle size $\mathrm{Z}<\mathrm{Y}$ ) with particle sizes less than $\mathrm{Y}$ pass directly through the BTB gap and subsequently affect spermatogenesis. N: nucleus; MF: microfilament. 


\section{MATERIALS AND METHODS}

\section{Chemicals}

$\mathrm{TiO}_{2}$-NPs (3 nm and $24 \mathrm{~nm}$ ) were purchased from JCNANO (Nanjin, China). The ultrastructural characteristics of $\mathrm{TiO}_{2}-\mathrm{NPs}$ are shown in Supplementary Figure 1.

\section{Cell line}

TM-4 cells from ATCC were maintained at $37^{\circ} \mathrm{C}$ with $5 \% \mathrm{CO}_{2}$ in DMEM/F12 (Genom, China) supplemented with $1.25 \%$ fetal bovine serum, $2.5 \%$ horse serum (Zhejiang Tianhang Biotechnology, China), and 100 $\mathrm{U} / \mathrm{ml}$ penicillin/streptomycin. When $50 \%$ cell confluence was achieved, different concentrations of $\mathrm{TiO}_{2}$-NPs ( $3 \mathrm{~nm}$ and $24 \mathrm{~nm}$ ) were added, and the cells were incubated for $24 \mathrm{~h}$.

\section{Cell viability assay}

TM-4 cells in 96-well plates were treated with various concentrations $(0,6.25,12.5,25,50,75$ and 100 $\mu \mathrm{g} / \mathrm{mL}$ ) of $\mathrm{TiO}_{2}$-NPs $(3 \mathrm{~nm}$ and $24 \mathrm{~nm}$ ) for $24 \mathrm{~h}$. Then, TM-4 cell viability was determined using the Cell Counting Kit-8 (Beyotime, China). OD450 values were determined using the multiplate reader Multiskan FC (Thermo).

\section{Western blotting}

TM-4 cells were lysed in RIPA buffer (Beyotime, China) with $1 \%$ protease inhibitor (Beyotime, China). Samples were separated by electrophoresis and transferred to PVDF membranes (Millipore, USA). Then, the samples were incubated with primary antibodies (Table 1) at $4^{\circ} \mathrm{C}$ overnight and incubated with secondary HRP-conjugated antibodies the next day for $1 \mathrm{~h}$ at room temperature (RT). The images were detected using an enhanced chemiluminescent kit (Beyotime, China). The bands were quantified using ImageJ.

\section{Immunofluorescence}

TM-4 cells were fixed in ethanol for $10 \mathrm{~min}(\mathrm{ZO}-1)$ or $4 \%$ paraformaldehyde for $15 \mathrm{~min}$ ( $\mathrm{N}$-cadherin, $\beta$ catenin and F-actin). After washing three times and blocking with $5 \%$ BSA for $1 \mathrm{~h}$, TM-4 cells were incubated with Actin-Tracker Green or ZO-1 antibody for $1 \mathrm{~h}$ and $\mathrm{N}$-cadherin or $\beta$-catenin antibody overnight at $4^{\circ} \mathrm{C}$ followed by incubation with Alexa Fluor 555/488 donkey-anti-rat/mouse IgG (Beyotime, China). Nuclei were stained blue with DAPI (Beyotime, China). After mounting with Antifade Mounting Medium
(Beyotime, China), the samples were detected using a confocal laser-scanning microscope (CLSM 510) (Carl Zeiss, Germany).

\section{Cell apoptosis assay}

A Caspase 3/8/9 Activity Assay Kit (Beyotime, China) was used to assess caspase 3/8/9 activity. TM-4 cells in 6-well plates were treated with $\mathrm{TiO}_{2}$-NPs for $24 \mathrm{~h}$ and then digested with trypsin for $2 \mathrm{~min}$. Total proteins were extracted using RIPA buffer (Beyotime, China). The supernatants were collected by centrifugation at 13,000 $\mathrm{rpm}$ for $15 \mathrm{~min}$ at $4^{\circ} \mathrm{C}$. The test buffer, the samples, and Ac-DEVD/IETD/LEHD-pNA $(2 \mathrm{mM})$ were added to 96 -well plates and incubated at $37^{\circ} \mathrm{C}$ for $2-4 \mathrm{~h}$ or overnight. Then, OD405 was measured. Protein concentrations were measured using the Bradford method to calculate the units of caspase 3/8/9 activity per sample based on the units of weight protein.

For the TUNEL apoptosis assay, TM-4 cells were fixed in $4 \%$ PFA for $30 \mathrm{~min}$ and permeabilized in $0.3 \%$ Triton X-100 for $5 \mathrm{~min}$. Then, samples were incubated with TUNEL test solution (Beyotime, China) for $1 \mathrm{~h}$ at $37^{\circ} \mathrm{C}$. Nuclei were stained blue with DAPI (Beyotime, China). After mounting with Antifade Mounting Medium (Beyotime, China), the samples were detected using a confocal laser-scanning microscope (CLSM 510) (Carl Zeiss, Germany).

\section{Determination of hydrogen peroxide levels and catalase (CAT) activity}

Intracellular hydrogen peroxide levels and intracellular CAT activity were determined using a hydrogen peroxide assay kit (Beyotime, China) and catalase assay kit (Beyotime, China), respectively.

Briefly, for the determination of intracellular hydrogen peroxide, a 50- $\mu$ l sample was added to a 96-well plate. Then, $100 \mu l$ hydrogen peroxide detection reagent was added and mixed well. Then, the mixture was incubated at RT for 30 minutes, and the OD546 was immediately measured. The concentration of intracellular hydrogen peroxide was calculated based on the standard curve.

For the determination of intracellular CAT, $2 \mu \mathrm{l}$ sample, $38 \mu \mathrm{l}$ catalase test buffer were added into the centrifuge tube, then with another $10 \mu \mathrm{l}$ of $250 \mathrm{mM}$ hydrogen peroxide solution, the mixture was incubated at $25^{\circ} \mathrm{C}$ for 1-5 min. Then, $450 \mu \mathrm{l}$ catalase reaction stop solution was added to stop the reaction. Ten microliters of the above mixture was added to $40 \mu \mathrm{l}$ catalase assay buffer. After mixing well, the mixture was added to color working solution in a 96-well plate. The cells were incubated at $25^{\circ} \mathrm{C}$ for at least $15 \mathrm{~min}$, and then the 
Table 1. Antibodies used for different experiments.

\begin{tabular}{|c|c|c|c|c|}
\hline Antibody & Host species & Vendor & Catalog number & Application(s)/dilution(s) \\
\hline $\begin{array}{l}\text { Anti- } \beta \text {-actin rabbit } \\
\text { polyclonal antibody }\end{array}$ & rabbit & Sangon Biotech & D110001 & WB(1:2000) \\
\hline ZO-1 Antibody & rabbit & Proteintech Group & 21773-1-AP & WB(1:500) \\
\hline $\mathrm{c}-\mathrm{Src}(\mathrm{B}-12)$ & mouse & Santa Cruz Biotechnology & sc-8056 & WB(1:200) \\
\hline $\begin{array}{l}\text { Anti-ACTR3 rabbit } \\
\text { polyclonal antibody }\end{array}$ & rabbit & Sangon Biotech & D154021 & WB(1:1000) \\
\hline Annexin II(H-50) & rabbit & Santa Cruz Biotechnology & sc-9061 & WB(1:200) \\
\hline Occludin Antibody & rabbit & Proteintech Group & 13409-1-AP & WB(1:500), IF(1:50) \\
\hline Anti-claudin 5 & rabbit & Abcam & ab15106 & WB(1:1000), IF(1:200) \\
\hline $\begin{array}{l}\beta \text {-catenin mouse } \\
\text { monoclonal antibody }\end{array}$ & mouse & Beyotime & AF0069 & WB(1:600), IF(1:200) \\
\hline $\begin{array}{l}\text { N-Cadherin rabbit } \\
\text { polyclonal antibody }\end{array}$ & rabbit & Beyotime & AF0243 & WB(1:500), IF(1:500) \\
\hline Actin-Tracker Green & rabbit & Beyotime & C1033 & $\operatorname{IF}(1: 100)$ \\
\hline
\end{tabular}

WB, western blotting; IF, immunofluorescence analysis.

OD520 was measured. Intracellular CAT activity was calculated based on the standard curve of CAT.

\section{Data analysis}

Graphical analysis was performed using GraphPad Prism 7. The data were expressed as the mean \pm SEM. Student's t-test was used to study statistical significance between two groups. One-way ANOVA was used to study statistical significance between multiple groups.

\section{AUTHOR CONTRIBUTIONS}

Dong-Qi Ni: Conceptualization, Methodology, Software, Visualization, Data collection and curation; Investigation, Formal analysis, Writing-Original Draft, Review and Editing; Dan-Dan Ma: Conceptualization, Visualization, Data curation, Investigation, Formal analysis, WritingReview and Editing; Shuang-Li Hao: Conceptualization, Visualization, Data curation, Investigation, Formal analysis, Writing-Review and Editing; Wan-Xi Yang: Conceptualization, Supervision, Writing -Review and Editing, Resources; Tamas Kovacs: Conceptualization, Methodology, Writing-Review and Editing, Resources; Fu-Qing Tan: Conceptualization, Methodology, Writing -Review and Editing, Resources, Funding acquisition.

\section{ACKNOWLEDGMENTS}

The authors are grateful to all members of the Sperm Laboratory at Zhejiang University for their valuable assistance with the present work.

\section{CONFLICTS OF INTEREST}

The authors declare that they have no conflicts of interest.

\section{FUNDING}

This project was supported in part by the Zhejiang Provincial Basic Public Welfare Research Project (including Natural Science Foundation) (No. LGF20C120001).

\section{REFERENCES}

1. Mascarenhas MN, Flaxman SR, Boerma T, Vanderpoel $S$, Stevens GA. National, regional, and global trends in infertility prevalence since 1990: a systematic analysis of 277 health surveys. PLoS Med. 2012; 9:e1001356. https://doi.org/10.1371/journal.pmed.1001356 PMID:23271957

2. Carlsen E, Giwercman A, Keiding N, Skakkebaek NE. Evidence for decreasing quality of semen during past 50 years. BMJ. 1992; 305:609-13. https://doi.org/10.1136/bmj.305.6854.609 PMID:1393072

3. Mruk DD, Cheng CY. Environmental contaminants: Is male reproductive health at risk? Spermatogenesis. 2011; 1:283-90.

https://doi.org/10.4161/spmg.1.4.18328

PMID:22332111

4. Ema M, Okuda H, Gamo M, Honda K. A review of reproductive and developmental toxicity of silver nanoparticles in laboratory animals. Reprod Toxicol. 2017; 67:149-64. https://doi.org/10.1016/j.reprotox.2017.01.005 PMID:28088501

5. Liu L, He Y, Xiao Z, Tao W, Zhu J, Wang B, Liu Z, Wang M. Effects of Selenium Nanoparticles on Reproductive 
Performance of Male Sprague-Dawley Rats at Supranutritional and Nonlethal Levels. Biol Trace Elem Res. 2017; 180:81-9.

https://doi.org/10.1007/s12011-017-0980-8

PMID:28261763

6. Nel A, Xia T, Mädler L, Li N. Toxic potential of materials at the nanolevel. Science. 2006; 311:622-7.

https://doi.org/10.1126/science.1114397

PMID:16456071

7. Horie $\mathrm{M}$, Kato $\mathrm{H}$, Fujita $\mathrm{K}$, Endoh $\mathrm{S}$, Iwahashi $\mathrm{H}$. In vitro evaluation of cellular response induced by manufactured nanoparticles. Chem Res Toxicol. 2012; 25:605-19.

https://doi.org/10.1021/tx200470e PMID:22136515

8. Oberdörster G, Oberdörster E, Oberdörster J. Nanotoxicology: an emerging discipline evolving from studies of ultrafine particles. Environ Health Perspect. 2005; 113:823-39.

https://doi.org/10.1289/ehp.7339 PMID:16002369

9. Oberdörster G, Maynard A, Donaldson K, Castranova V, Fitzpatrick J, Ausman K, Carter J, Karn B, Kreyling W, Lai D, Olin S, Monteiro-Riviere N, Warheit D, Yang H, and ILSI Research Foundation/Risk Science Institute Nanomaterial Toxicity Screening Working Group. Principles for characterizing the potential human health effects from exposure to nanomaterials: elements of a screening strategy. Part Fibre Toxicol. 2005; 2:8.

https://doi.org/10.1186/1743-8977-2-8

PMID:16209704

10. Campbell A, Oldham M, Becaria A, Bondy SC, Meacher D, Sioutas C, Misra C, Mendez LB, Kleinman M. Particulate matter in polluted air may increase biomarkers of inflammation in mouse brain. Neurotoxicology. 2005; 26:133-40.

https://doi.org/10.1016/i.neuro.2004.08.003 PMID:15527881

11. Zhang XF, Gurunathan S, Kim JH. Effects of silver nanoparticles on neonatal testis development in mice. Int J Nanomedicine. 2015; 10:6243-56.

https://doi.org/10.2147/IJN.S90733 PMID:26491295

12. Castellini C, Ruggeri S, Mattioli S, Bernardini G, Macchioni L, Moretti E, Collodel G. Long-term effects of silver nanoparticles on reproductive activity of rabbit buck. Syst Biol Reprod Med. 2014; 60:143-50. https://doi.org/10.3109/19396368.2014.891163 PMID:24547726

13. Li X, Yang X, Yuwen L, Yang W, Weng L, Teng Z, Wang L. Evaluation of toxic effects of CdTe quantum dots on the reproductive system in adult male mice. Biomaterials. 2016; 96:24-32. https://doi.org/10.1016/i.biomaterials.2016.04.014
PMID:27135714

14. Asare N, Instanes C, Sandberg WJ, Refsnes $M$, Schwarze P, Kruszewski M, Brunborg G. Cytotoxic and genotoxic effects of silver nanoparticles in testicular cells. Toxicology. 2012; 291:65-72.

https://doi.org/10.1016/j.tox.2011.10.022 PMID:22085606

15. Shukla RK, Kumar A, Pandey AK, Singh SS, Dhawan A. Titanium dioxide nanoparticles induce oxidative stressmediated apoptosis in human keratinocyte cells. J Biomed Nanotechnol. 2011; 7:100-1. https://doi.org/10.1166/jbn.2011.1221 PMID:21485823

16. Jia F, Sun Z, Yan X, Zhou B, Wang J. Effect of pubertal nano- $\mathrm{TiO}_{2}$ exposure on testosterone synthesis and spermatogenesis in mice. Arch Toxicol. 2014; 88: 781-8.

https://doi.org/10.1007/s00204-013-1167-5 PMID:24241477

17. Hong F, Wang Y, Zhou Y, Zhang Q, Ge Y, Chen M, Hong J, Wang L. Exposure to $\mathrm{TiO}_{2}$ Nanoparticles Induces Immunological Dysfunction in Mouse Testitis. J Agric Food Chem. 2016; 64:346-55.

https://doi.org/10.1021/acs.jafc.5b05262 PMID:26720763

18. Gao G, Ze Y, Zhao X, Sang X, Zheng L, Ze X, Gui S, Sheng L, Sun $Q$, Hong J, Yu X, Wang L, Hong F, Zhang X. Titanium dioxide nanoparticle-induced testicular damage, spermatogenesis suppression, and gene expression alterations in male mice. J Hazard Mater. 2013; 258:133-43.

https://doi.org/10.1016/i.jhazmat.2013.04.046 PMID:23721730

19. Meena R, Kajal K, Paulraj R. Cytotoxic and genotoxic effects of titanium dioxide nanoparticles in testicular cells of male wistar rat. Appl Biochem Biotechnol. 2015; 175:825-40.

https://doi.org/10.1007/s12010-014-1299-y

PMID:25344432

20. Li N, Mruk DD, Chen $\mathrm{H}$, Wong $\mathrm{CK}$, Lee WM, Cheng CY. Rescue of perfluorooctanesulfonate (PFOS)-mediated Sertoli cell injury by overexpression of gap junction protein connexin 43. Sci Rep. 2016; 6:29667.

https://doi.org/10.1038/srep29667 PMID:27436542

21. Lie PP, Chan AY, Mruk DD, Lee WM, Cheng CY. Restricted Arp3 expression in the testis prevents blood-testis barrier disruption during junction restructuring at spermatogenesis. Proc Natl Acad Sci USA. 2010; 107:11411-6. https://doi.org/10.1073/pnas.1001823107 PMID:20534520 
22. Li N, Mruk DD, Lee WM, Wong CK, Cheng CY. Is toxicant-induced Sertoli cell injury in vitro a useful model to study molecular mechanisms in spermatogenesis? Semin Cell Dev Biol. 2016; 59: 141-56.

https://doi.org/10.1016/i.semcdb.2016.01.003

PMID:26779951

23. Reis MM, Moreira AC, Sousa M, Mathur PP, Oliveira PF, Alves MG. Sertoli cell as a model in male reproductive toxicology: Advantages and disadvantages. J Appl Toxicol. 2015; 35:870-83. https://doi.org/10.1002/jat.3122 PMID:25693974

24. Schrade A, Kyrönlahti A, Akinrinade O, Pihlajoki $M$, Fischer S, Rodriguez VM, Otte K, Velagapudi V, Toppari J, Wilson DB, Heikinheimo M. GATA4 Regulates BloodTestis Barrier Function and Lactate Metabolism in Mouse Sertoli Cells. Endocrinology. 2016; 157: 2416-31.

https://doi.org/10.1210/en.2015-1927 PMID:26974005

25. Roumaud $\mathrm{P}$, Martin $\sqcup$. Transcriptomic analysis of overexpressed SOX4 and SOX8 in TM4 Sertoli cells with emphasis on cell-to-cell interactions. Biochem Biophys Res Commun. 2019; 512:678-83.

https://doi.org/10.1016/i.bbrc.2019.03.096 PMID:30922563

26. Zhou Y, Geng X, Chen Y, Shi H, Yang Y, Zhu C, Yu G, Tang Z. Essential roles of Akt/Snail pathway in microcystin-LR-induced tight junction toxicity in Sertoli cell. Food Chem Toxicol. 2018; 112:290-8.

https://doi.org/10.1016/i.fct.2018.01.004 PMID:29307602

27. Lan Z, Yang WX. Nanoparticles and spermatogenesis: how do nanoparticles affect spermatogenesis and penetrate the blood-testis barrier. Nanomedicine (Lond). 2012; 7:579-96.

https://doi.org/10.2217/nnm.12.20 PMID:22471721

28. Xiao X, Mruk DD, Tang EI, Wong CK, Lee WM, John CM, Turek PJ, Silvestrini B, Cheng CY. Environmental toxicants perturb human Sertoli cell adhesive function via changes in F-actin organization mediated by actin regulatory proteins. Hum Reprod. 2014; 29:1279-91. https://doi.org/10.1093/humrep/deu011 PMID:24532171

29. Xiao X, Yang Y, Mao B, Cheng CY, Ni Y. Emerging role for SRC family kinases in junction dynamics during spermatogenesis. Reproduction. 2019; 157:R85-94. https://doi.org/10.1530/REP-18-0440 PMID:30608903

30. Mather JP. Establishment and characterization of two distinct mouse testicular epithelial cell lines. Biol Reprod. 1980; 23:243-52. https://doi.org/10.1095/biolreprod23.1.243

\section{PMID:6774781}

31. Mather JP, Zhuang LZ, Perez-Infante V, Phillips DM. Culture of testicular cells in hormone-supplemented serum-free medium. Ann N Y Acad Sci. 1982; 383: 44-68.

https://doi.org/10.1111/i.1749-6632.1982.tb23161.x PMID:

32. Liu Q, Xu C, Ji G, Liu H, Mo Y, Tollerud DJ, Gu A, Zhang Q. Sublethal effects of zinc oxide nanoparticles on male reproductive cells. Toxicol In Vitro. 2016; 35:131-8. https://doi.org/10.1016/j.tiv.2016.05.017 PMID:27247145

33. Xiao X, Mruk DD, Cheng FL, Cheng CY. C-Src and c-Yes are two unlikely partners of spermatogenesis and their roles in blood-testis barrier dynamics. Adv Exp Med Biol. 2012; 763:295-317.

https://doi.org/10.1007/978-1-4614-4711-5 15 PMID:23397631

34. Xiao X, Wong EW, Lie PP, Mruk DD, Wong CK, Cheng $\mathrm{CY}$. Cytokines, polarity proteins, and endosomal protein trafficking and signaling-the sertoli cell bloodtestis barrier system in vitro as a study model. Methods Enzymol. 2014; 534:181-94.

https://doi.org/10.1016/B978-0-12-397926-1.00010-X PMID:24359954

35. Hong $F$, Zhao $X$, Chen $M$, Zhou $Y$, Ze $Y$, Wang L, Wang $Y$, Ge Y, Zhang Q, Ye L. $\mathrm{TiO}_{2}$ nanoparticles-induced apoptosis of primary cultured Sertoli cells of mice. J Biomed Mater Res A. 2016; 104:124-35. https://doi.org/10.1002/jbm.a.35548 PMID:26238530

36. Jiang XH, Bukhari I, Zheng W, Yin S, Wang Z, Cooke HJ, Shi QH. Blood-testis barrier and spermatogenesis: lessons from genetically-modified mice. Asian J Androl. 2014; 16:572-80.

https://doi.org/10.4103/1008-682X.125401 PMID:24713828

37. Zhang XF, Choi YJ, Han JW, Kim E, Park JH, Gurunathan $\mathrm{S}$, Kim JH. Differential nanoreprotoxicity of silver nanoparticles in male somatic cells and spermatogonial stem cells. Int J Nanomedicine. 2015; 10:1335-57. https://doi.org/10.2147/IJN.S76062 PMID:25733828

38. Thakur M, Gupta H, Singh D, Mohanty IR, Maheswari $U$, Vanage G, Joshi DS. Histopathological and ultra structural effects of nanoparticles on rat testis following 90 days (Chronic study) of repeated oral administration. J Nanobiotechnology. 2014; 12:42.

https://doi.org/10.1186/s12951-014-0042-8 PMID:25311086

39. Peng F, Setyawati MI, Tee JK, Ding X, Wang J, Nga ME, Ho HK, Leong DT. Nanoparticles promote in vivo breast cancer cell intravasation and extravasation by inducing endothelial leakiness. Nat Nanotechnol. 2019; 14: 
279-86.

https://doi.org/10.1038/s41565-018-0356-z

PMID:30692675

40. Ye L, Hong F, Ze X, Li L, Zhou Y, Ze Y. Toxic effects of $\mathrm{TiO}_{2}$ nanoparticles in primary cultured rat sertoli cells are mediated via a dysregulated $\mathrm{Ca}^{2+} / \mathrm{PKC} / \mathrm{p} 38$ MAPK/NF-kB cascade. J Biomed Mater Res A. 2017; 105:1374-82.

https://doi.org/10.1002/jbm.a.36021 PMID:28188686

41. Mao Z, Yao M, Xu B, Ji X, Jiang H, Han X, Tang Q, Zhou $Z$, Chen R, Li X, Xia Y. Cytoskeletons of Two Reproductive Germ Cell Lines Response Differently to Titanium Dioxide Nanoparticles Mediating Vary Reproductive Toxicity. J Biomed Nanotechnol. 2017; 13:409-16.

https://doi.org/10.1166/jbn.2017.2360

PMID:29384604

42. Ma DD, Yang WX. Engineered nanoparticles induce cell apoptosis: potential for cancer therapy. Oncotarget. 2016; 7:40882-903.

https://doi.org/10.18632/oncotarget.8553 PMID:27056889

43. Warheit DB, Webb TR, Reed KL, Frerichs S, Sayes CM. Pulmonary toxicity study in rats with three forms of ultrafine- $\mathrm{TiO}_{2}$ particles: differential responses related to surface properties. Toxicology. 2007; 230:90-104. https://doi.org/10.1016/j.tox.2006.11.002 PMID:17196727

44. Gao Y, Chen H, Xiao X, Lui WY, Lee WM, Mruk DD, Cheng CY. Perfluorooctanesulfonate (PFOS)-induced Sertoli cell injury through a disruption of F-actin and microtubule organization is mediated by Akt1/2. Sci Rep. 2017; 7:1110. https://doi.org/10.1038/s41598-017-01016-8 PMID:28439067

45. González-Mariscal L, Tapia R, Chamorro D. Crosstalk of tight junction components with signaling pathways. Biochim Biophys Acta. 2008; 1778:729-56. https://doi.org/10.1016/j.bbamem.2007.08.018 PMID:17950242

46. Furuse $\mathrm{M}$, Hirase $\mathrm{T}$, Itoh $\mathrm{M}$, Nagafuchi $\mathrm{A}$, Yonemura $\mathrm{S}$, Tsukita S, Tsukita S. Occludin: a novel integral membrane protein localizing at tight junctions. J Cell Biol. 1993; 123:1777-88.

https://doi.org/10.1083/icb.123.6.1777

PMID: $\underline{8276896}$

47. Lacaz-Vieira F, Jaeger MM, Farshori P, Kachar B. Small synthetic peptides homologous to ssegments of the first external loop of occludin impair tight junction resealing. J Membr Biol. 1999; 168:289-97.

https://doi.org/10.1007/s002329900518

PMID:10191363

48. González-Mariscal L, Betanzos A, Avila-Flores A. MAGUK proteins: structure and role in the tight junction. Semin Cell Dev Biol. 2000; 11:315-24.

https://doi.org/10.1006/scdb.2000.0178 PMID:10966866

49. Wolburg $H$, Lippoldt A. Tight junctions of the bloodbrain barrier: development, composition and regulation. Vascul Pharmacol. 2002; 38:323-37. https://doi.org/10.1016/s1537-1891(02)00200-8 PMID: $\underline{12529927}$

50. Morrow CM, Tyagi G, Simon L, Carnes K, Murphy KM, Cooke PS, Hofmann MC, Hess RA. Claudin 5 expression in mouse seminiferous epithelium is dependent upon the transcription factor ets variant 5 and contributes to blood-testis barrier function. Biol Reprod. 2009; 81:871-9.

https://doi.org/10.1095/biolreprod.109.077040 PMID:19571261 


\section{SUPPLEMENTARY MATERIALS}

\section{Supplementary Figures}
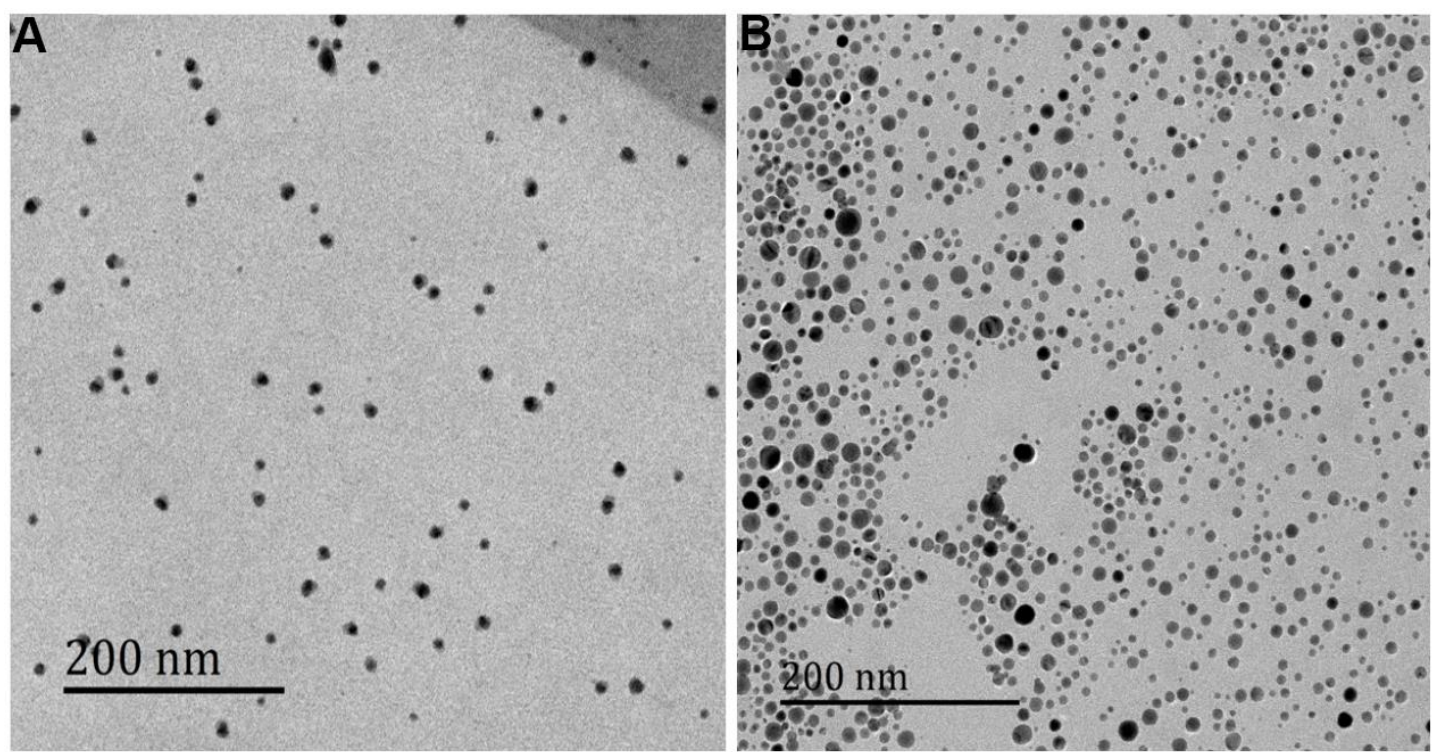

Supplementary Figure 1. $\mathrm{TiO}_{2}-\mathrm{NP}$ transmission electron microscopy. (A) 3-nm $\mathrm{TiO}_{2}-\mathrm{NPs}$ and (B) 24-nm $\mathrm{TiO}_{2}-\mathrm{NPs}$ (transmission electron micrographs were provided by Nanjing Jicang Nano Technology).
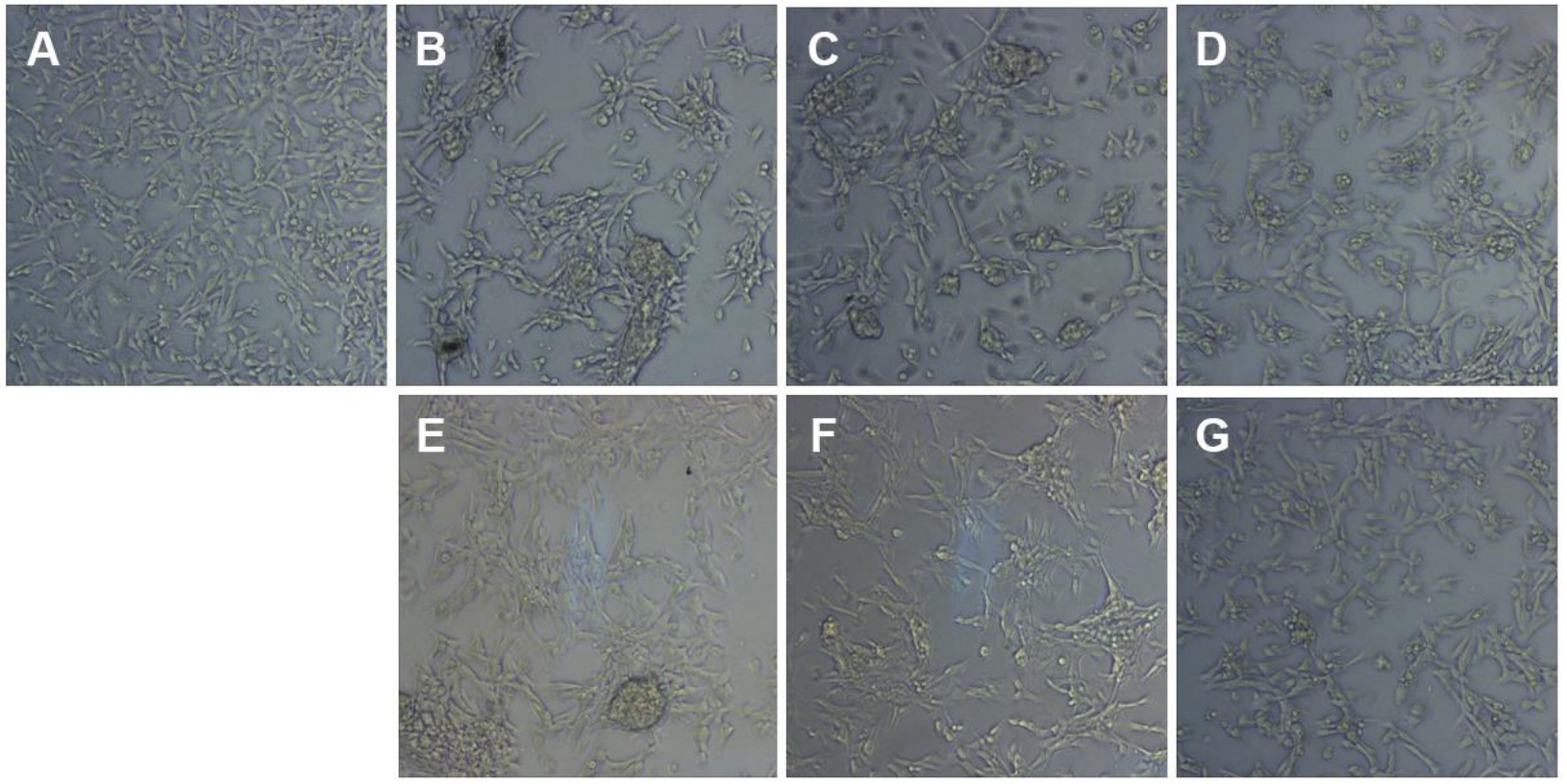

Supplementary Figure 2. Morphological changes in TM-4 cells treated with $\mathrm{TiO}_{2}-\mathrm{NPs}$. (A) Control group, (B) $30 \mu \mathrm{g} / \mathrm{ml}^{3}-\mathrm{nm} \mathrm{TiO}{ }_{2}-$ $\mathrm{NP}$ treatment for $24 \mathrm{~h},(\mathrm{C}) 60 \mu \mathrm{g} / \mathrm{ml} 3-\mathrm{nm} \mathrm{TiO}_{2}-\mathrm{NP}$ treatment for $24 \mathrm{~h}$, (D) $60 \mu \mathrm{g} / \mathrm{ml} 3-\mathrm{nm} \mathrm{TiO}-\mathrm{NP}_{2}$ treatment for $24 \mathrm{~h}$ prior to treatment with $\mathrm{NAC}$ for $2 \mathrm{~h}$, (E) $30 \mu \mathrm{g} / \mathrm{ml}$ 24-nm TiO $2-\mathrm{NP}$ for $24 \mathrm{~h}$, (F) $60 \mu \mathrm{g} / \mathrm{ml}$ 24-nm TiO $2-\mathrm{NP}$ for $24 \mathrm{~h}$, and (G) $60 \mu \mathrm{g} / \mathrm{ml} 24-\mathrm{nm} \mathrm{TiO}_{2}-\mathrm{NP}$ treatment for $24 \mathrm{~h}$ prior to treatment with NAC for 2 h. $\times 100$. 